\title{
Helsingin yliopiston kasvatustieteen laitoksen aikuiskoulutuksen tutkimushankkeet
}

\section{Seppo Kontiainen, Antti Kauppi ja Anna Harlamov}

Suunnitelmallinen muutos ja aikuiskoulutuksen suunnittelu

Projektin tarkoituksena on kehittää välineitä ja metodeja aikuiskoulutustutkimusta varten. Projektissa keskitytään mm.

- analysoimaan aikuiskoulutuksen suunnittelun teoreettisia perusteita,

- analysoimaan muutosten suunnittelua suhteessa aikuiskoulutukseen ja opetusoppimisprosessin suunnitteluun,

- käyttämään hyväksi monitieteellistä lähestymistapaa aikuiskoulutuksen suunnittelussa,

- kehittämään suunnittelutoiminnassa tarvittavia päätöksentekomalleja.

Projektissa keskitytään parhaillaan koulutuksen suunnitteluun, erityisesti työnopetukseen liittyvän teoriapohjan selvittämiseen suomalaisessa koulutustraditiossa. Suunnitelmallista muutosta tarkastellaan myös kansalais- ja työväenopiston opettajien työn kehittämiseen sitoutuneena.

\section{Singa Sandelin}

\section{Osien ja kokonaisuuden ymmärtäminen}

Kasvatustieteellisessä tutkimuksessa on perinteisesti korostettu yksityiskohtien merkitystä. Viime aikoina on ryhdytty näitä yksityiskohtia kokoamaan kokonaisvaltaisiksi toiminnallisiksi järjestelmiksi. Tällöin tutkija kohtaa aivan uudenlaisia metodologisia ja filosofisia ongelmia.

Tutkimuksessa suuntaudutaan näiden ongelmien jäsentämiseen systeemiajattelun avulla huomioiden todellisuuden hierarkinen järjestäytyminen, toiminnallinen luonne, sitoutuminen erilaisissa maailmankuvissa sekä todellisuudessa ilmenevien järjestelmien laadullisen muuttumisen.

\section{Ritva Lindroos \\ Arkikokemuksellisuus opetuksen tavoitteena}

Saksan liittotasavallassa on 1970- ja 1980-luvuilla keskusteltu reflektiivisestä käänteestä aikuiskasvatuksessa. Tällöin on vaadittu osallistujien huomioon ottamista sovittaessa opetuksen tavoitteista, sisällöistä ja menetelmistä. Osallistujakeskeisyyden edellytyksenä on nähty uuden tiedon persoonallisen merkityksen luominen oppijan arkikokemuksen kautta.

Koulutukseen osallistuminen ja yleensäkin aikuiskoulutuksen merkitys on voitava perustella järkevästi. Tämä on nimetty koulutuksen legitimaatio-ongelmaksi.

Tutkimuksen ensimmäisessä osassa legitimaatiokysymystä on tarkasteltu reflektoivan oppimisnäkemyksen valossa. Etualalla on ollut reflektiivisyys opiskelijoiden ja opettajien kommunikaatiokäyttäytymisessä.

Tutkimus jatkuu biografiatutkimuksena. Tutkimuksen käytännöllinen viitekehys on työllisyyskoulutus.

\section{Yrjö Engeström \\ Toiminnan teoria ja kehittävä työntutkimus}

Työprosessin perinteinen määrittely on johtanut siihen, että työhön kohdistuvia psykologisia tutkimuksia ja perusteltu joko työn rationalisoinnilla tai sen humanisoinnilla. Työn sosiologiset tutkimukset ovat perustuneet kvalifikaatio- ja polarisaatioteorioille. Muutoksen ja kehityksen kollektiivinen hallinta on tullut työtoiminnan keskeiseksi ongelmaksi ja samalla korkeatasoinen oppiminen on muodostunut entistä tärkeämmäksi työn hallinnan kannalta.

Kehittävän työtutkimuksen ja toiminnan te orian perusteita selvittävä väitöskirja Learning by expanded on valmistunut. Lisäksi terveyskeskuslääkärien työn kehittämistä koskeva tutkimus on meneillään. 
Terttu Kanniainen

Ammatillisen

aikuiskoulutuksen ja

työelämän välisen

merkityksen

tutkimusprojekti

Tutkimusprojektissa tarkastellaan ammatillisen aikuiskoulutuksen ja työelämän välisiä suhteita aikuiskoulutuksessa vallitsevan muutosparadigman mukaan. Projektissa on tällä hetkellä kaksi eri tutkimushanketta:

1. Korkeakoulujen yrittäjäkoulutuksen seurantatutkimus (yhteistyössä Turun kauppakorkeakoulun hallinnon ja markkinoinnin laitos sekä Helsingin yliopiston osuustoimintaopín laitos). Tutkimuksessa tarkastellaan korkeakoulujen työllisyysvaroilla järjestämää yrittäjäkoulutusta kokonaisvaltaisesti ottaen huomioon yrittäjäkoulutuksen suunnittelu- ja toteutusvaiheet sekä koulutuksen lyhyen ja pitkän aikavälin vaikutukset. Projektin perimmäisenä tavoitteena on kokonaisvaltaisen koulutuksen seurantajärjestelmän luominen "sisäänrakennettuna" yrittäjäkurssitoimintaan.

2. Työelämässä vaadittavan metallityön sisällön vastaavuuden arviointi suhteessa keskiasteen metallialan koulutukseen. Tutkimuksessa tarkastellaan metallialan työn arvostusta keskiasteen oppilaitoksien opiskelijoilla sekä sitä, miten metallialan ammattien ammattimielikuvat muotoutuvat koulutuksen aikana ja välittömästi koulutuksen jälkeen siirryttäessä työelämään. Tutkimus suoritetaan pitkittäistutkimuksena.

\section{Juha Varila}

Koetun koulutustarpeen

käsite ja sen asema aikuisopiskelijan opetus-oppimisprosessia suunniteltaessa

Tutkija pyrkii löytämään koetun koulutustarpeen käsitteellistämisen ehtoja, paikantamaan se yhteyksiinsä sekä osoittamaan, miten koettua koulutustarvetta voidaan hyödyntää aikuisten oppimisprosessia suunniteltaessa.

\section{Urpo Sarala}

Työelämän koulutuksen ja

tutkimuksen haasteita

aikuiskasvatuksen opetukselle ja tutkimukselle

Organisaatiojohto näkee koulutuksen merkityksen organisaationsa kehittämisessä hyvin kapeasti. Uudemmat liikkeenjohdon suuntauk- set avartavat koulutuksen merkitystä organisaatiokulttuurin, työmotivaation ja kilpailuasetelmien kehittämisen suuntaan.

Tutkijan väitöskirja "Henkilöstökoulutuksen mahdolisuudet teollisuusyrityksen kehittämisessä. Tapausesimerkkinä ASKO-koulutusprojekti" valmistui syksyllä -86. Tutkija jatkaa organisaation kehittämiseen liittyvää työskentelyä sekä lisäksi oppimateriaalin tuottamista.

\section{Terttu Gröhn}

Opiskelijoiden käsitykset omaan tieteenalaansa

liittyvistä ilmiöistä ja käsitysten muuttuminen korkeakouluopintojen

\section{kuluessa}

Tutkijan tarkoituksena on seurata korkeakouluopiskelijoiden oppimisprosessia heidän omasta näkökulmastaan käsin: miten opiskelijoiden käsitykset joistakin omaan tieteenalaansa liittyvistä ilmiöistä muuttuvat opiskelun eri vaiheissa. Tarkoituksena on tutkia opiskelijoita kolmessa eri vaiheessa: opiskelua aloitettaessa, aineopintojen päättämisvaiheessa ja juuri ennen opiskelun päättymistä.

\section{Kari E. Nurmi, Anna Harlamov ja Tuija Laurén Avoimen korkeakoulun opetusmuotojen kehittäminen}

Projektissa tarkastellaan yliopistotasoisen etäopetuksen opetustapahtumaa ja pyritään hahmottamaan opiskelijan ja opettajan suhdetta niiden vaikutuksien taustaa vasten, joita opiskelija kokee kirjeopiskelussa. Teoreettisesti kuvataan opinto-ohjausta, opiskelumotivaatiota sekä opiskelijan ja etäopettajan ihmissuhdetta. Projektista on valmistunut kolme tutkimusraporttia.

\section{Ilse Stjernberg \\ Tutkimusprojekti \\ eri ikäisten \\ naisten minäkuvasta}

Tutkimusprojekti on kehityspsykologinen ja sen kohteena ovat 30-60-vuotiaat naiset. Kiinnostus kohdistuu minäkuvassa havaittaviin eroihin eri ikäisillä naisilla. Tutkimusprojektissa käsitellään työminäkuvaa, sosiaalista ja fyysistä minäkuvaa sekä yleistä minäkuvaa. Projektista on julkaistu tutkimukset: Naisopettajien loppuunpalaminen ja Eri ikäisten naisten minäkuva. 